\title{
TAKING THE PLUNGE: RECREATIONAL WATER QUALITY GUIDELINES
}

Cris Hickey

Beachwatch Programs

NSW Environment Protection Authority

\section{Christine Cowie}

Water Unit

NSW Department of Health

During the 1980s, the profile of recreational water quality at Sydney's beaches caused concern among Sydneysiders. Monitoring of recreational water quality indicated that most Sydney beaches had poor water quality, and this condition was attributed to the disposal of partiallytreated sewage at cliff-face discharges. ${ }^{1}$ An epidemiological study conducted in 1989-1990 attempted to determine the prevalence of disease that might have been attributed to the water quality at the time. ${ }^{2}$ Since then, major improvements to sewage disposal practices in Sydney have seen corresponding improvements in water quality. ${ }^{3}$

This article describes the current move in Australia, and by the World Health Organization (WHO), to review existing recreational water quality guidelines. Anticipating the release of new draft National Health and Medical Research Council (NHMRC) guidelines for recreational water quality, which are likely to be influenced by the WHO guidelines, the approach was trialled by applying it to data collected by Beachwatch. Beachwatch is the recreational water quality monitoring program administered by the NSW Environment Protection Authority. The different approaches to estimating the health risk produced different results for the water quality at 35 Sydney beaches. Possible reasons for these differences are discussed.

\section{HEALTH EFFECTS ASSOCIATED WITH RECREATIONAL WATER QUALITY}

Recreational exposure to contaminated beach water has been associated with gastroenteritis, respiratory illness, eye infections, ear-nose-throat infections, and skin and mucosal infections. ${ }^{4} \mathrm{~A}$ review of the literature conducted in 1998, on behalf of the WHO, evaluated the health risk attributable to recreational water quality. ${ }^{5}$ The author reviewed 22 of 36 studies that met specific epidemiological criteria, two of these studies being randomised controlled trials (RCT). The two RCTs reported threshold levels of $>32$ faecal streptococci/100 $\mathrm{mL}$ for increased risk of gastroenteritis, 60 faecal streptococci/100 mL for acute febrile respiratory illness, and 100 faecal coliforms $/ 100 \mathrm{~mL}$ for ear ailments. Gastrointestinal symptoms were the most common outcome for which significant dose-response relationships were reported in the WHO review. One overseas study reported higher attack rates for gastroenteritis in visitors to a locality compared to the resident population, suggesting that immune status may play a role in the presentation of illness. This suggests that populations may differ in their susceptibility to waterborne diseases.

\section{TABLE 1}

RECREATIONAL WATER QUALITY GUIDELINES IN USE IN NSW AND AUSTRALIA

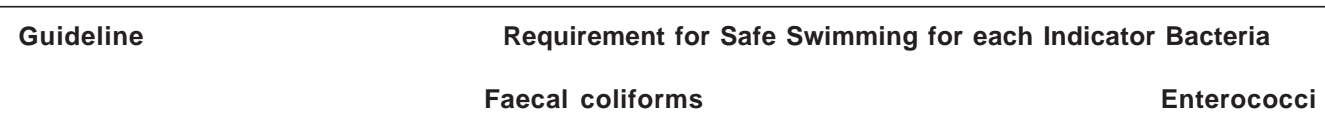

NHMRC, $1990^{6}$

median value $<150 \mathrm{cfu} / 100 \mathrm{~mL}$ for a minimum of 5 samples taken at regular intervals not exceeding 1 month AND 4 out of 5 samples $<600 \mathrm{cfu} / 100 \mathrm{~mL}$ *

ANZECC, 1992, $2000^{7}$

median value $<150 \mathrm{cfu} / 100 \mathrm{~mL}$ for a minimum of 5 samples taken at regular intervals not exceeding 1 month AND 4 out of 5 samples $<600 \mathrm{cfu} / 100 \mathrm{~mL}$

Beachwatch $^{3}$

median value $<150 \mathrm{cfu} / 100 \mathrm{mLfor}$ a minimum of 5 samples taken at regular intervals not exceeding 1 month AND 4 out of 5 samples $<600 \mathrm{cfu} / 100 \mathrm{~mL}$ geometric mean of $33 / 100 \mathrm{~mL}$ for marine waters

median value $<35 / 100 \mathrm{~mL}$ for a minimum of 5 samples AND

$60-100 / 100 \mathrm{~mL}$ maximum number in any one sample

median value $<35 / 100 \mathrm{~mL}$ for a minimum of 5 samples taken at regular intervals not exceeding 1 month AND

4 out of 5 samples $=$ or $<100 / 100 m L$

* $\mathrm{cfu} / 100 \mathrm{~mL}=$ colony forming units per 100 millilitres of water. 
Although indicator organisms used in the WHO review studies varied, the organisms that correlated best with disease outcomes were enterococci and faecal streptococci for both marine and freshwaters, and E. coli for freshwater. ${ }^{5}$ However, correlations were also reported for faecal coliforms and staphylococci. ${ }^{5}$

\section{RECREATIONAL WATER QUALITY GUIDELINES}

Although many of the symptoms associated with recreational water exposure are due to infection by enteric viruses, for pragmatic reasons recreational water quality is determined by 'indicator' bacterial organisms. Three recreational water quality guidelines currently used in NSW and Australia are listed in Table 1. Although quite similar, there are subtle differences in terms of frequency of monitoring and the statistics used. Beachwatch uses a combination of both NHMRC guidelines and Australian and New Zealand Environment Conservation Council (ANZECC) guidelines. ${ }^{6,7}$

\section{APPLICATION OFTHE WHO DRAFT GUIDELINES: METHODOLOGY AND RESULTS}

Draft recreational water quality guidelines were released by WHO in $1998,{ }^{8}$ and more recently by the United States Environmental Protection Agency. ${ }^{9}$ The NHMRC generally uses the WHO guidelines as a basis for developing or reviewing Australian guidelines, and is currently reviewing the national recreational water quality guidelines.

The draft WHO guidelines enable water managers to set guideline values for swimming, based on the risk of beach users becoming ill. The values are determined using a known relationship between bacterial density and illness rates (the dose-response relationship), and the distribution of bacterial levels at a swimming site or representative group of sites (the probability distribution function, or pdf). The values can then be used to develop a beach classification system that promotes informed choice as a risk management strategy.
The WHO guidelines use the dose-response relationship derived from one of the RCT studies cited in the WHO review, conducted in English waters by Kay et al. ${ }^{10}$ This study reported a threshold level of $>32$ faecal streptococci/ $100 \mathrm{~mL}$ for increased risk of gastroenteritis. While the dose-response curve from this study is significantly steeper, and the threshold level lower, than those reported in previous studies, it is accepted by WHO on the basis that the study's robust epidemiological design minimises misclassification and more accurately measures the association between water quality and illness. ${ }^{8}$

The WHO approach was trialled, ${ }^{8}$ using data collected at 35 Sydney beaches under the Beachwatch Program. ${ }^{3}$ The Beachwatch Program measures levels of thermotolerant coliforms and enterococci only. For the purposes of this exercise, it was assumed that levels of enterococci in marine waters closely approximate levels of streptococci. This assumption is supported by the rapid die-off rate of the two streptococci species not included in the enterococci group.

A pdf for Sydney beaches was generated from data collected over the 1999-2000 summer season. Guideline values were then generated using the WHO methodology and these are listed in Table 2. Interestingly, the pdf distribution and guideline values for Sydney beaches were similar to those determined by WHO for European waters. ${ }^{8}$

WHO notes that its derived guideline values represent better water quality than presently encountered at many beaches worldwide. ${ }^{8}$ Table 3 indicates that this is the case for Sydney beaches, with many beaches that currently have high compliance with existing water quality guidelines (100 per cent compliance) receiving $\mathrm{B}$ and $\mathrm{C}$ classifications when the WHO dose-response relationship is utilised.

\section{DISCUSSION}

Before applying the guidelines to a specific area, WHO recommends that a wide range of social, environmental, cultural, and technical issues be considered, such as the

\section{TABLE 2}

EXAMPLE OF CLASSIFICATION SYSTEM FOR BEACHES BASED ON WHO DRAFT GUIDELINES, SYDNEY, NSW

\begin{tabular}{|lll|}
\hline Classification & Enterococci density at 95th percentile & Illness rates \\
\hline A & Less than $14 \mathrm{cfu} / 100 \mathrm{~mL}{ }^{*}$ & $<2.5 / 1000$ \\
$\mathrm{~B}$ & 14 to $49 \mathrm{cfu} / 100 \mathrm{~mL}$ & $2.5-12.5 / 1000$ \\
$\mathrm{C}$ & 50 to $198 \mathrm{cfu} / 100 \mathrm{~mL}$ & $12.5-50 / 1000 \quad$ \\
$\mathrm{D}$ & 199 to $1000 \mathrm{cfu} / 100 \mathrm{~mL}$ & Contamination \\
$\mathrm{E}$ & Greater than $1000 \mathrm{cfu} / 100 \mathrm{~mL}$ & Public health risk requiring \\
& & immediate investigation
\end{tabular}

Source: Based on World Health Organization Guidelines for Safe Recreational-water Environments: Coastal and Freshwaters. Draft for Consultation, Geneva, October $1998 .{ }^{8}$

* cfu/ $100 \mathrm{~mL}=$ colony forming units per 100 millilitres of water. 


\section{TABLE 3}

CLASSIFICATION OF BEACHES AND PER CENT COMPLIANCE WITH BEACHWATCH GUIDELINES FOR ENTEROCOCCI DURING THE SUMMER SEASON, SYDNEY, NSW, 2001-2002

\begin{tabular}{|c|c|c|c|}
\hline Beach & $\begin{array}{l}\text { Enterococci } \\
95 \text { percentile } \\
(\mathrm{cfu} / 100 \mathrm{~mL}){ }^{\star *}\end{array}$ & $\begin{array}{c}\text { Classification } \\
\text { using } \\
\text { WHO categories }\end{array}$ & $\begin{array}{l}\% \text { Compliance with } \\
\text { Beachwatch } \\
\text { guidelines * }\end{array}$ \\
\hline Palm Beach & 74 & $\mathrm{C}$ & 100 \\
\hline Whale Beach & 16 & B & 100 \\
\hline Avalon & 32 & $\mathrm{~B}$ & 100 \\
\hline Bilgola & 26 & $\mathrm{~B}$ & 100 \\
\hline Newport & 22 & B & 100 \\
\hline Bungan & 16 & $\mathrm{~B}$ & 100 \\
\hline Mona Vale & 14 & $A$ & 100 \\
\hline Warriewood & 28 & B & 100 \\
\hline Turimetta & 22 & $\mathrm{~B}$ & 100 \\
\hline Nth Narrabeen & 14 & A & 100 \\
\hline Collaroy & 50 & $\mathrm{~B}$ & 100 \\
\hline Long Reef & 6 & A & 100 \\
\hline Dee Why & 110 & $\mathrm{C}$ & 100 \\
\hline Nth Curl Curl & 54 & $\mathrm{C}$ & 88 \\
\hline Sth Curl Curl & 16 & B & 100 \\
\hline Freshwater & 100 & $\mathrm{C}$ & 97 \\
\hline Queenscliff & 80 & $\mathrm{C}$ & 94 \\
\hline Nth Steyne & 78 & C & 97 \\
\hline Sth Steyne & 80 & $\mathrm{C}$ & 97 \\
\hline Shelly Beach (Manly) & 84 & $\mathrm{C}$ & 88 \\
\hline Bondi & 80 & $\mathrm{C}$ & 88 \\
\hline Tamarama & 100 & $\mathrm{C}$ & 84 \\
\hline Bronte & 60 & C & 100 \\
\hline Clovelly & 120 & $\mathrm{C}$ & 75 \\
\hline Coogee & 120 & $\mathrm{C}$ & 84 \\
\hline Maroubra & 110 & $\mathrm{C}$ & 78 \\
\hline Malabar & 170 & $\mathrm{C}$ & 84 \\
\hline Boat Harbour & 130 & C & 72 \\
\hline Greenhills & 16 & B & 100 \\
\hline Wanda & 24 & B & 100 \\
\hline Elouera & 26 & $\mathrm{~B}$ & 100 \\
\hline Nth Cronulla & 34 & B & 100 \\
\hline Sth Cronulla & 40 & B & 100 \\
\hline Shelly Beach (Sutherland) & 44 & B & 100 \\
\hline Oak Park & 86 & C & 100 \\
\hline \multicolumn{4}{|c|}{$\begin{array}{l}\text { * Source: Beachwatch. Beachwatch and Harbourwatch 2001-2002 State of the Beaches Report. Sydney, } \\
\text { NSW Environment Protection Authority, 2003. }{ }^{3}\end{array}$} \\
\hline \multicolumn{4}{|c|}{${ }^{* *} \mathrm{cfu} / 100 \mathrm{~mL}=$ colony forming units per 100 millilitres of water. } \\
\hline
\end{tabular}

nature and seriousness of local endemic illness, population behaviour, and exposure patterns. Three key issues that should be considered, when results from the two methods are compared, are outlined below.

\section{Is the 95th percentile an appropriate statistic?}

Beachwatch collects samples every six days at Sydney beaches. Elevated bacterial counts are most frequently recorded during and immediately after heavy rainfall. As the pdf of bacterial data for Sydney beaches includes bacterial levels collected during wet weather, the 95 percentile represents the poorer water quality during wet weather. Anecdotal evidence indicates that most of the community generally does not swim during or immediately after rainfall, and it may be therefore inappropriate to determine health risk and a beach classification based on this statistic.

\section{Is the WHO dose-response relationship appropriate?}

WHO notes that the dose-response curve developed by Kay et al. may not cover all global climatic conditions nor all recreational water types. ${ }^{8}$ As Kay's study was conducted in northern European waters, ${ }^{10}$ it is possible 
that this dose-response relationship is not applicable for the Sydney region where a threshold more representative of warmer waters may be more appropriate. Varying climatic and oceanographic conditions such as differing water temperatures can effect the spatial distribution and survival of pathogens in bodies of water. ${ }^{11}$

Sydney also has an extended swimming season (from beginning of October to end of April), compared to northern Europe, with many beachgoers visiting beaches frequently during the season. As a result of this greater exposure (longer and more often), it is possible that Sydney swimmers may have higher or a different immune response to swimming-associated illness. ${ }^{2}$

\section{Is faecal streptococci the best indicator?}

The results of the Sydney Beach Users Study differ from Kay et al. in that faecal coliforms were found to be a better predictor of reported symptoms than were faecal streptococci. ${ }^{2}$ The study found that swimmers were almost twice as likely than non-swimmers to report symptoms, and that there was evidence of increasing reporting of symptoms for all symptoms (other than gastrointestinal symptoms) with increasing bacterial counts, suggesting a dose-response relationship.

\section{CONCLUSION}

As the success of the WHO approach relies on a doseresponse relationship that accurately defines the illness rates associated with swimming for a specific population, it may not be appropriate to apply the WHO methodology in NSW before this relationship is accurately defined by a robust epidemiological study. Such studies are, however, costly and resource intensive to conduct. Further, it is anticipated that the application of the WHO guideline methodology could be onerous for many local councils to implement.

Other factors that need to be considered before applying the WHO guidelines are the levels at which acceptable or tolerable excess disease rates are set for the NSW community, and the pattern of variability in the distribution of bacterial levels at Sydney beaches over time.

\section{REFERENCES}

1. Kueh CSW, Grohmann GS. Recovery of viruses and bacteria in waters off Bondi beach: A pilot study. Med J Aust 1989; 151: 632-638.

2. Corbett SJ, Rubin GL, et al. The health effects of swimming at Sydney beaches. The Sydney Beach Users Advisory Group. Am J Public Health 1993; 83:1701-06.

3. Beachwatch. Beachwatch and Harbourwatch 2001-2002 State of the Beaches Report. Sydney, NSW Environment Protection Authority, 2003.

4. World Health Organization. Bathing Water Quality and Human Health. Protection of the Human Environment-Water, Sanitation and Health. Geneva: World Health Organization, 2001.

5. Pruss A. Review of epidemiological studies on health effects from exposure to recreational water. Int J Epidemiology 1998; 27(1): 1-9.

6. National Health \& Medical Research Council. Australian guidelines for recreational use of water. Canberra: National Health \& Medical Research Council, 1990.

7. Australian \& New Zealand Environment \& Conservation Council, Agriculture \& Resource Management Council of Australia \& New Zealand. Australian and New Zealand Guidelines for Fresh and Marine Water Quality. Canberra: Environment Australia, 2000.

8. World Health Organization. Guidelines for Safe Recreationalwater Environments: Coastal and Freshwaters: Draft for Consultation. Geneva: World Health Organization, 1998.

9. US Environmental Protection Agency. Implementation Guidance for Ambient Water Quality Criteria for Bacteria. Draft. Washington DC: US Environmental Protection Agency, 2002.

10. Kay D, Fleisher JM et al. Predicting likelihood of gastroenteritis from sea bathing: Results from randomised exposure. Lancet 1994; 344: 905-09.

11. Mourino-Perez RR. Studying the risks of ocean swimming. Epidemiology 1999; 10(4); 351-352. WH 